\title{
Book Review of The Devil's Delusion
}

\section{Book Review of}

The Devil's Delusion: Atheism and its Scientific Pretensions, by David Berlinski (2008) Crown Forum, New York, USA, pp. 237.

The ancient Greeks were said to be looking for an honest man, whereas our trouble today is trying to find an honest physicist...and maybe even an honest scientist. But, by golly, I think I found him, and he has written this book which belongs in every science class from high school through college. It is a delight to read, filled with wisdom and insights about the socalled scientists who are theophobic and actually counterphobic whenever considering that somewhere, someplace, somebody may be getting genuine joy and virtue from their belief in God.

Berlinski destroys the promotions of prominent atheists who have been prancing around for the last several years

including Christopher Hitchins, Sam Harris, Daniel Dennett, and the ultimate atheist conman himself, Richard Dawkins, discovered by me to be a flagrant liar and academic sham (The press as First Amendment frauds have censored my reporting this but it is available if you email me for it at sam@docnigro.com). With trenchant analysis, Berlinski destroys their unscience (a very good word for Darwin and all his followers). He does this not only by readily understandable language but with a delightful chuckle on almost every page-It is a "Yeah. He is right. Why didn't everyone think of that?" As a psychiatrist I answer for all:

We overlook the fact that scientists are human too...so suggestible like everyone else; so pompous and arrogant; and so self-promoting like everyone else; and thus untrustworthy whenever not looking into their microscopes. I just finished The Day Without Yesterday by John Farrell, and found out, among a million other things discrediting to scientists, how the name "Hubble's Law" was given to the discovery of Georges Lamaitre-a dastardly historical outrage-and scientists, historians and journalists do not give a damn. The truism is this: Unless proven otherwise, scientists are shameless disgraces (approaching that of journalists) when preaching about something not seen in their microscopes. I propose Richard Dawkins as the lying conman paradigm for all scientists who go public. And not to be forgotten is that Galileo himself fraudulently claimed to have invented the telescope while trying to get funding from the Venetian Senatethey laughed at him as they booted him out. Scientists are often like journalists and lawyers-you can tell they are lying because their lips are moving whenever they pretend to know what they are talking about.

This book delightfully teaches how to think more deeply and see through all the atheistic nonsense foisted on us the past several decades, but, in spite of that, one will be surprisingly entertained at the good natured but deflating needling Berlinski does to the atheist posers of science.

I was so entertained and enthused, I could not put the book down and devoured it in one reading. The arrogant flatulence of

Volume 3 Issue 6 - 2015
Dr. Samuel A Nigro M.D*
Retired, Assistant Clinical Professor Psychiatry, Case Western
Reserve University School of Medicine, USA
*Corresponding author: Dr. Samuel A Nigro M.D, Retired,
Assistant Clinical Professor Psychiatry, Case Western Reserve
University School of Medicine, 2517 Guilford Road, Cleveland
Heights, Ohio 44118, USA, Tel: 216 932-0575; Email:
sam@docnigro.com
Received: October 07, 2015 | Published: October 08, 2015

science with its pompous never proven cliches has never been better shown to be suggestible flim-flam which it almost always is when expanded beyond its concrete specifics. Unbeatable is George Gilder's review of The Devil's Delusion as follows:

Bill Buckley, in his final days, declared: "Berlinski's book is everything desirable; it is idiomatic, profound, brilliantly polemical, amusing, and of course vastly learned. I congratulate him." Buckley was right, as usual. It is the definitive book of the new millennium.

Strongly recommended, and scientists, historians and journalists be damned. 